$J J M L L$

\title{
ENGAGE Model as an Innovation in Teaching Speaking: A Case of Cognitively More and Less Active EFL Learners
}

\author{
Shahram Esfandiari, Asgar Mahmoudi*, Mehran Davaribina \\ Department of English Language Teaching, Islamic Azad University, Ardabil Branch, Iran
}

Received on: 9-8-2020

Accepted on: 28-12-2020

\begin{abstract}
This study investigated the effect of using the ENGAGE Model on the speaking performance of cognitively more and less active EFL learners. The participants of the study were 60 intermediate level male EFL learners who were non-randomly selected from a pool of intermediate students $(\mathrm{N}=80)$ based on their performance on a standard version of Preliminary English Test (PET). The selected participants were assigned to the two groups of the ENGAGE Model and Task-based Language Teaching (TBLT). They were also specified in terms of their cognitive ability as cognitively more or less active learners based on their answers to a validated cognitive profile questionnaire. The results revealed that learners in the ENGAGE Model group outperformed students in the TBLT group in terms of their L2 speaking, regardless of whether they belonged to the cognitively less or more active group. It was also concluded students with a cognitively more active profile benefit more from the ENGAGE Model.
\end{abstract}

Keywords: Cognition, ENGAGE Model, Speaking Performance, TBLT, EFL Learners.

\section{Introduction}

Proficiency in speaking skill is of priority to a lot of second or foreign language learners. The reason lies in the fact that speaking, as a significant skill, is the prime means of communication (Hughes 2013; Kim and Craig 2012; Richards 2008). Many L2 research studies (Ghanizadeh et al. 2018; Pica and Doughty 1985; Sundqvist and Sylvén 2016; Yang et al. 2013) support the importance of L2 speaking as well as the role of comprehensible input in facilitating L2 development in the classroom context. Although this skill has attracted attention in EFL/ESL courses in a variety of social circumstances, the ways of approaching the educational issues associated with L2 speaking such as low fluency of EFL learners, their minimized accuracy for the sake of fluency, and using prefabricated language items, have been at the center of methodological discussions for a long time (Albino 2017; Celce-Murcia 1991; Ellis 2008; Watts and Huensch 2013; Yang et al. 2013).

Among the modern approaches gaining success in the educational setting, one can refer to Halsey's (2011) naturalistic-oriented educational proposal, namely the Energizing, Navigating, Generating, Applying, Gauging, and Extending (ENGAGE) Model, in her book titled Brilliance by Design, which paved the way for the emergence of educational program changes in America, especially in California,

๑๑ 2021 JJMLL Publishers/Yarmouk University. All Rights Reserved,

${ }^{*}$ Doi: https://doi.org/ 10.47012/jjmll.13.4.8

* Corresponding Author: Mahmoudi301@gmail.com 
where Halsey and Halsey (2017) and Halsey, Halsey, and Gaudette (2018) used the model to develop an educational program stressing environmental issues to increase awareness concerning wildlife and protecting the environment. The present authors have tried to employ the same perspective in designing an L2 speaking method in which the six steps stressed by Halsey (2011) could be followed. In addition, since Halsey's model is closely connected to mental progression and engaging learners' mind and mentality, its presence in an L2 classroom through a cognitive approach can enrich effective teaching and learning.

From the cognitivists' point of view, learning is the result of effective information organization and processing. Hence, cognition of the learners and their cognitive abilities require specific attention by educators. Based on Jordan, Carlile, and Stack (2008), when educators understand the ways through which information is processed, designing the learning experiences for optimization of such activities will be possible for them (34). Accordingly, it seems that awareness of the ways through which short-term memories are transferred by the learners into meaningful data can contribute significantly in the learning contexts. Likewise, within cognitive load theory, learning a second language follows a cognitive perspective relying on principles of sensation, perception, attention, encoding and memory (Leahy and Sweller 2016). Today, current attempts in language classrooms need to focus on aural intake by negotiating the meaning actively with other people (hereafter, peers). Such mutual meaning negotiation of the speakers will motivate cognitive as well as socio-cognitive processes which are essential to acquire the language (Pica and Doughty 1985). In this regard, it is felt that there is a shortage of interdisciplinary studies aiming at combining new findings of cognitive psychology (such as ENGAGE Model proposed in the current study) and L2 acquisition or learning in order to develop strong educational methods in teaching L2 in the world in general and in the Iranian context in particular (Akbari 2015).

Though old traditional and modern methods of language teaching have found their way to the Iranian educational system (Safari and Rashidi 2015), to the knowledge of the present researchers, the ENGAGE Model has not been employed as a teaching method in the English Language Teaching (ELT) domain in the Iranian context yet. Nor has it been examined in the development of teaching techniques in the L2 classroom to help teachers using other methods involve their learners in the environmental, social, and cognitive issues, which in turn could improve critical thinking, social understanding, and intercultural literacy (Takimoto 2020).

Considering the ever growing demand of Iranian EFL learners for fluent and effective speaking, the present study was an attempt to compare the two methods of Task based Language Teaching (TBLT) (as one of the current English teaching practices in Iran) and the ENGAGE Model as an innovative perspective developed based on Halsey (2011), for teaching L2 speaking to the cognitively more and cognitively less active EFL learners. The fact is that EFL students need a more student-centred approach which fosters a collaborative learning incorporating peer tutoring and group working (Ockey et al. 2015). In this regard, the researchers tried to adopt an approach to teaching embedded in naturalist theories focusing on active engagement of learners in the learning process, like the one introduced by Halsey (2011) called the ENGAGE Model. In fact, "the basic message of the ENGAGE Model is that people 
ENGAGE Model as an Innovation in Teaching Speaking: A Case of

Cognitively More and Less Active EFL Learners

learn best when they play an active, critical role in the learning process, apply what they have learned, and are encouraged to discover their own meanings to places and things" (Halsey and Halsey 2017, 4). Fluent and effective teaching would take form in a conducive and favorable environment which is believed can be prepared by employing the ENGAGE Model.

\section{Literature Review}

\subsection{Cognitive learning}

Cognitive learning, which is rooted in cognition and cognitive load theory, encompasses five basic processes of "sensation, perception, attention, encoding and memory, all of which have implications for the process of learning" (Jordan et al. 2008, 34). Learners with different cognitive orientations are likely to behave differently in the process of L2 development. In this regard, Kalyuga and Singh (2016) proposed that cognitive learning is manifested in the boundaries of Cognitive Load Theory (CLT) in complex learning activities such as mathematics, foreign language development, and logics. Learners with high cognitive ability are labeled as cognitively more active learners as they can use their senses, attention, imagination, and coding systems to improve their abilities in learning new vocabularies, specific structures, absorbing writing styles, successful learning strategies and the like (Takimoto 2020). However, less cognitively active learners might not be able to attend to the significant points in piece of reading or use valuable structures in their writings (Murphy 2019). Hence, it could be assumed that cognitively more active learners would have a better performance compared to cognitively less active ones in these subjects. This could be observed in the way each group uses both cognitive and metacognitive strategies in problem solving (Asaoka 2019). Murphy (2019) found that cognitively more active learners are faster than their cognitively less active counterparts in diagnosing the learning problems of their peers, using metacognitive nurturing in the L2 classroom more effectively, and doing cyclically designed deep-thinking tasks better. They also have higher strategic competence. In addition, Soboleva (2019) found that individuals with high levels of cognition can suggestively benefit more from learnercentered teaching methods as their creativity and autonomy would be highlighted in such methods.

Cognition, which is rooted in cognitive learning theories, mainly focuses on the mental processes of gaining knowledge and information through thinking, experiencing, and sensing. According to Adams (2015), memory, perception, and mental imagery are the main factors involved in the learning process. It is argued that cognition plays a significant role in the learning process in general and in L2 development in particular (Anderson and Krathwohl 2001). In this regard, symbolic psychologic approach, which is considered as a model of attitudinal cognition, has focused on both more and less cognitively active learners and has emphasized that cognition has a significant position in attitude change (Rosenberg and Abelson 2017). Psychologically speaking, the term cognition is often accompanied with information processing within the domain of cognitivism (Sternberg and Sternberg 2009). Human cognition, as Eysenck and Keane (2013) in their seminal book "Cognitive Psychology" argue, could be considered as conscious and unconscious, concrete or abstract, as well as intuitive (like knowledge of a language) and conceptual (like a model of a language). 


\section{Esfandiari, Mahmoudi, Davaribina}

The field of cognitive psychology has pushed the limits of our knowledge by making available sophisticated devices to study learning processes through observing human brain in action (Eysenck and Keane 2018). According to Eysenck and Keane (2013), cognitive psychology takes the inner procedures engaged in making sense of the context, while decisions made about the proper actions are also considered. Such procedures consist of attention, perception, learning, memory, language, problem solving, reasoning, and thinking. According to the definition proposed by Cacioppo et al. (2008), cognitive psychology involves the efforts to figure out human cognition through observation of the individuals' behaviors when carrying out different cognitive activities (62). Based on the definition provided by Cacioppo and Freberg (2018), cognitive neuroscience involves the efforts to utilize information regarding the behaviors and the brain to understand human cognitive status (8). Jordan et al. (2008) argue that experimental cognitive psychology has vastly influenced the development of cognitive learning and in particular has found that individuals could be more or less active in terms of their cognition. L2 learners, either low or high in terms of cognition level use serial, parallel, top-down, and bottom-up processes types in their learning (Harley 2004). Cognitive psychologists presuppose the involvement of the top-down and bottom-up processes in carrying out cognitive tasks. Such processes may be followed serially or in parallel. Despite the significant role of cognitive psychology, its ecologic validity fails at times, leading to its suffering from paradigm specificity, and making it theoretically vague (Eysenck and Keane 2018). However, cognitive psychology has provided the SLA researchers with new paths which could be used in understanding the complicated concept of learning a second language, solving problems through creative cognitive strategies such as critical thinking and concept mapping.

\subsection{The ENGAGE Model}

The ENGAGE Model of education, with its great impact on the learning and teaching profession (Rundel 2018), supports learning of a second language, as a natural, brilliance-oriented process in which engagement in natural and socially mediated activities seems necessary. It considers self-instruction as a vital factor to authentic development that should be accompanied with self-assessment and personal gauging (Halsey 2011). It is a program which covers various educational levels from primary schools to high schools and universities and focuses on the learners not teachers for the instructional design and delivery (Halsey 2011).

Halsey (2011) proposed that the brain can be doing anything while being focused on a lecture delivered by a teacher in the classroom, and it continuously does. She also asserted that traditional approaches to teaching cannot engage the learner's mind as they mainly focus on teacher fronting methods and lecturing. Teachers' authority and centrality in the EFL classroom might decrease the concentration of learners' mind on the main points as they will not be provided with enough room to be creative, use their brind (brain and mind) effectively (Halsey 2016). Halsey and Halsey (2017) have suggested that naturalist education programs should apply active learning methods aimed at engaging the mind. ENGAGE Model introduced by Halsey (2011) is among these methods, which takes a six step approach toward teaching content with the use of active learning strategies in combination with employment of meaningful interpretations (Halsey and Halsey 2017, 8). It is argued that the ENGAGE 
ENGAGE Model as an Innovation in Teaching Speaking: A Case of

Cognitively More and Less Active EFL Learners

Model is a model where students are actively engaged in mastering knowledge and skills and applying them to a real problem utilizing technological tools available. Nevertheless, assisting people in more engagement in their own learning processes is a difficult task, requiring confident audacious trainers to make learners participate and inclined to perform the kinds of activities proposed by the model, because most of us are accustomed to sit-and-get passive methods. Meanwhile, if educators actually want learners to remember what they have taught and to use that knowledge in order to change their behaviors, learner involvement is a crucial factor to be taken into consideration (Borg and Alshumaimeri 2019; Halsey and Halsey 2017; Zhang et al. 2019).

Halsey and Halsey (2017) proposed working based on these six steps to help others in learning, remembering, and caring about the content aimed to be shared:

Step 1. Energize Learners. The start of optimum learning is when individuals are energized prior to the start of the class.

Step 2. Navigate Content. This step proposes a hint to the content via short discussions along with photographs, outlines, as well as written materials. At the same time a variety of activities are suggested to permit the learners "teach back" the materials to peers (including acting, demonstrating, using games, telling stories, jig-saw learning, interactive discussions, and so on).

Step 3. Generate Meaning. After the main content is captured by the learners via the above steps, educators assist them to enhance the meaning associated with the content through application of meaningful interpretations.

Step 4. Apply Learning. New memories are generated by the learners along with deepening the content knowledge with the application of the learned materials.

Step 5. Gauge and Celebrate Learning. It is essential to check for understanding to ensure that the correct knowledge has been grasped by the learners together with the establishment of meanings. Gauging self-assessments in learning contexts can be useful in this regard.

Step 6. Extend Learning to Action. Learning is kept alive with the creation of a procedure to promote further meanings, higher levels of curiosity, and closer associations with the subject.

To sum up, the fundamental message of the ENGAGE Model is that students learn well when they play a crucial and active role in the process of learning. Moreover, the best way of learning is when the learners apply what they have learned, and when they are encouraged to discover their own meanings of things and places (Halsey and Halsey 2017).

Kim et al. (2017) used the ENGAGE Model in the domain of nursing practices and found benefits of an EvidenceBased Practice (EBP) fellowship program. In this regard, they found "improvement in EBP beliefs had direct impacts on developments in job satisfaction of the participants" (90). Likewise, Glance, Rhinehart, and Brown (2018) have developed a model for teaching clinical skills in the helping professions namely, Learn, Expand, and Engage (LEE) which has been inspired by Halsey's (2011) ENGAGE Model. Their teaching model was provided based on constructivist philosophies, learneroriented and flipped-classroom educational methods. With the usage and incorporation of strong features of different fields, the model aims at enabling postsecondary educators of establishing contexts for 
learning that would assist students to achieve the highest levels of learning illustrated in the revised version of Bloom's Taxonomy (Brown 2007). As they indicated, the LEE model can provide a framework for higher education instruction with direct response to a currently determined requirement for competency-oriented student learning education in the helping professions ( 104).

Highlighting the environmental issues connected with Chaparral ecosystems and specific and iconic vegetation of California, Rundel (2018) developed an educational program for the operationalization of ecosystem knowledge of the students for turning the tide on urbanization, land-use change and protection of endangered species (1). Underwood et al. (2018) also propose that the ENGAGE Model can be used for curriculum development in the educational settings aiming at paving the ground for more awareness toward the environment, wildlife, global issues, and consequently more responsible life-long learning.

\section{$2.3 T B L T$}

Task-based language teaching, which can be seen as the strong version of Communicative Language Teaching (CLT), recommends language use as the main aim of language learning (Ellis 2009). Ellis (2003) states that "in TBLT the syllabus specifications are based on communicative tasks and not on notions and functions or grammatical structure" (123). Nunan (2006) has defined communicative pedagogical tasks as those pieces of classroom activities involving learners in comprehension, manipulation, production or interaction in the target language with their attention primarily concentrated on the meaning instead of the form (24). A good number of studies have already proved the significant impact of TBLT on the L2 speaking development in both ESL and EFL contexts (Buriro and Hayat 2010; Ellis 2009; Hismanoglu and Hismanoglu 2011; Prabhu 1987; Rohani 2011; Yamada and Knight 2001; Zheng and Borg 2014). Moreover, it is possible to support the students to express meanings and assist them in the development of linguistic forms with the application of recasts and prompts (Guchte et al. 2015). In the present study, TBLT was used in the control group.

\subsection{L2 speaking}

A large number of language learners worldwide study English to be able to communicate effectively. The ability to speak a second or foreign language as well as possible can be considered a really sophisticated task for a lot of non-native speakers of that language, i.e., English (Kang 2005). Speaking is utilized for a variety of objectives such as contacting socially with people, establishment of rapport, engagement in discussions with others, illustrating opinions, encouraging others about something, or clarification of information (Richards and Renandya 2002). During the past decades or so, linguists have supplied a significant amount of information on how speakers utilize language in an appropriate way in various conditions and illustrated the complicated nature of what is involved in the development of spoken fluency in second or foreign languages (Hedge 1993).

Language learners have to exploit their knowledge for the production of a message. Listening and reading are facilitating factors for speaking, since students learn new words and forms at the same time that they listen and read and because they have to learn comprehension of oral as well as written messages prior to their production themselves. This is while they have to speak in order to enhance their 
ENGAGE Model as an Innovation in Teaching Speaking: A Case of

Cognitively More and Less Active EFL Learners

speaking skills (Nunan 2003). Also, speaking requires students to activate their linguistic knowledge, along with their general knowledge of the world, in a way that is different from that required in the other three language skills (Kang 2005). Likewise, Albino (2017) considers speaking as a complex process in which many linguistic elements are involved including phonological, morphological, syntactic and semantic as well as discourse. Comprehending and producing appropriate language are important for EFL learners because failure to do so may cause frustration for both the speaker and the listener or to have their messages misunderstood (Rabab'ah and Rumman 2015). In a foreign language situation where students lack the need and opportunity for genuine communication in the target language, it would be difficult for students to develop their speaking ability (Toro et al. 2019).

A plethora of research have been conducted on EFL speaking classrooms at the international level (Albino 2017; Aljumah 2011; Guchte et al. 2015; Housen and Kuiken 2009; Jassem 1997; Kunnu and Sukwises 2014; Lee 2009; Nakatani 2010). Almost all these studies have concluded that EFL students need to be able to overcome the speaking breakdowns resulting from the lack of speaking activities in EFL classes (Ghaemi and Hassannejad 2015). A key aspect, for the EFL learners, in dealing with such a difficulty, is to know communication strategies. Therefore, there should be a crucial concern in our English classes for communication strategy instruction with a systematic method. The ENGAGE Model (Halsey 2011), which takes a relatively new approach to teaching content by using active learning techniques combined with utilizing meaningful interpretation, could be employed in teaching speaking.

Considering the purpose of the current study, the following research questions and null hypotheses were formulated:

Q1: Does the ENGAGE Model have any statistically significant effect on the speaking development of cognitively less active EFL learners?

Q2: Does the ENGAGE Model have any statistically significant effect on the speaking development of cognitively more active EFL learners?

Q3: Do cognitively more and less active EFL learners differ significantly in their speaking performance in response to being taught with the TBLT or the ENGAGE Model?

H01: The ENGAGE Model has no statistically significant effect on the speaking development of cognitively less active EFL learners.

H02: The ENGAGE Model has no statistically significant effect on the speaking development of cognitively more active EFL learners.

H03: Cognitively more and less active EFL learners do not differ significantly in their speaking performance in response to being taught with the TBLT or the ENGAGE Model.

\section{Method}

\subsection{Participants}

The participants of this study were 60 homogeneous intermediate level male students in the age range of 18 to 25 at one of the language institutes in Ardabil, Iran. The participants were chosen based on their performance in a standard Preliminary English Test (PET). In fact, they were the ones whose scores 
fell within 1Standard Deviation (SD) above and below the mean. This study included some safeguards to ensure that the participants' rights were in no way being violated. The researchers received the oral permission from the participants and they were aware that they were part of a study. The researchers

explained to the participants that their participation was voluntary, and that any information gathered from them in the study would be kept strictly confidential.

\subsection{Instrumentation}

To evaluate the general proficiency of the participants, the PET was used. This test has been designed primarily to evaluate the L2 proficiency of candidates at the intermediate level (Read and Hayes 2003). The administration of the whole test took 120 minutes. In the present study, the range of the scores of the selected participants whose scores were within 1 Standard Deviation (SD) above and below the mean was between 54 and 66 as the mean was 60.34 and the SD was 5.97. Likewise, The KR-21 reliability for the PET was.91.

The cognitive profile questionnaire was developed and validated by the researchers and was intended to measure the cognitive profile of the EFL learners. To construct the scale, the researchers did a thorough review of the literature, interviewed experts in the field, and developed an open-ended questionnaire which was answered by a group of $50 \mathrm{EFL}$ learners similar to the study's main participants in terms of age, gender, and educational background. The results were transcribed and analyzed through content analysis relying on open, axial, and selective coding system, as in grounded theory. Accordingly, a closeended questionnaire was developed and put to the scrutiny of three experts who were EFL university professors with a background in psychology. Following the process of modification based on suggestions of these experts, the scale was piloted among 245 Iranian EFL learners. The scale included 30 items and covered six domains of Engagement, Relationship, Persistence, Critical thinking, Planning, and Purposive learning. The reliability of the scale was calculated to be 0.86 based on Cronbach's alpha with 245 Iranian EFL learners. The content validity of the scale was also confirmed by 3 experts in TEFL relying on expert judgment validity. Construct validity of the scale was also confirmed through factor analysis confirming the loadings of the variables on all 6 factors of the scale.

The speaking pre-test instrument was a standard speaking test selected from among the PET series. It took 11-14 minutes and included three parts. In part 1, examinees answered questions about themselves and their family. In part 2, they spoke about a topic, and in part 3, the examinees had a longer discussion about the topic introduced in part 2. The speaking test was the same for both pre and post-tests of speaking. Speaking pre/post-tests included the sub components of fluency and coherence, lexical resource, grammatical range and accuracy, and pronunciation. It is worth mentioning that the time interval between the pre and post-tests of speaking was 8 weeks.

The inter-rater scoring method was used to score the learners' performance in the speaking test. The Pearson correlations were computed to estimate the inter-rater reliability indices for the two raters on the pre-tests and post-tests of speaking. For reliability and validity purposes, in addition to the one of the researchers, another rater scored the speaking tests. This rater had worked as an IELTS examiner and could rate the tests accurately. Based on the results, there was a significant agreement $(r=.843, \mathrm{P}=.001$ 
ENGAGE Model as an Innovation in Teaching Speaking: A Case of

Cognitively More and Less Active EFL Learners

$<.05)$ between the two raters on the pre-tests of speaking. Also, there was a significant agreement $(r$ $=.942, \mathrm{P}=.001<.05)$ between the two raters on the post-test of speaking.

\subsection{Procedure}

In the first phase of this study the standard PET was administered to a pool of 80 intermediate students. Out of this pool, based on the scale presented for scoring PET, a group of 60 students, whose scores fell between $1 \mathrm{SD}$ above and below the mean, were selected as the main participants of the study. The selected number of the participants was in line with Krejcie and Morgan's (1970) table of determining sample size for research activities which asserts that out of a pool of 80 subjects at least 60 to 66 individuals should be selected for a given study. The selected participants were randomly assigned to the two equal groups of the ENGAGE Model (the experimental group) and TBLT (the control group). In the second phase, a speaking pre-test was implemented for the participants in order to ensure a homogenous sample regarding their SL speaking performance. Based on the results, they had acceptable homogeneity regarding their second language speaking.

Treatment was provided in 16 sessions. The total semester consisted of 8 weeks and the learners had to attend the classes two days a week, and every session lasted 90 minutes. Both groups received the same hours of instruction and practice. In the experimental group (the ENGAGE Model), the teacher used principles of the ENGAGE Model (Halsey 2011). This model employs active learning strategies through naturalist education programs to engage the mind (Halsey 2016). Hence, the following general perspectives were taken into consideration in a language classroom at the intermediate level, which served as the experimental group of the study.

Step 1: Energizing the students at the beginning of any classroom session through making them involved in the warm ups, ice-breaking discussions, talking about daily life issues, and motivating them through using gestures and postures (of course cultural issues might be impeding which should be thought of; an example is laughing with the students and using motivating gestures, facial expressions, voice changing, and the like which are not common in the Iranian context).

Step 2: Asking the students to navigate what they have gained in the energizing session and develop the new content. This step could employ the process-based syllabus (White 1988) in which teachers and learners negotiate on decisions to be made about assignments and activities. This way the content of what was being taught was developed by the learners and the teacher monitored them to talk about their own interests and concerns.

Step 3: Helping the students generate personal meaning and connect what they have gained to their own life and what they feel given the new concepts they have learned and the topic(s) discussed in the classroom. This was done through asking the students to present oral reports to the classroom about the current events, their life and their feelings about recent events in the immediate social context and the like.

Step 4: Helping the students apply their learning to the real world. This was done via asking the students study about the topic selected in the classroom, use the internet, get involved in the social media, 
collect information about a specific issue, and then present their own perspectives in the classroom. In the next step, the students focused on what they could do to bring about a positive change in the social context and their own life.

Step 5: Making the learners gauge and celebrate their progress. This was possible through employing Self Assessment (SA) in the classroom context. SA has been discussed as an important tool for autonomous language learners (Bachman and Damböck 2018). At first, SA principles were taught to the learners and then they were trained to develop self-assessment checklists. Then they practiced self-assessment on the speaking activities and tasks. They scored their own performance based on the checklists they developed. Subsequently, they were asked to say how much they were ready for the coming steps and procedures. Also, they were asked to assess themselves at the end of each session of the classroom and see how well they had learned what had been taught. Of course, they received relative feedback by the teacher, something which was decreased as the learners increased in the quality of their self-assessment. Various quizzes and classroom discussions were presented in the intervention sessions. An example might clarify the issue: The first topic in the first lesson was making friends and the covered vocabularies were vocabulary related to TV shows, clothes, food, and weekend activities. Also, the students covered an article about giving advice. Were the students interested in this issue, the researcher might decide to use it for an interview or conversation topic. Furthermore, each student recorded a talk and sent it to her friends and received responses. Then, the students used the sentences from different sources and the Internet to make questions and asked each other to complete the exam papers they had developed. Naturally, the researcher checked the questions made by the students and finalized them. After answering the questions orally, the students themselves checked their answers to see if they were correct or not. Then they evaluated themselves as being excellent, good, bad, or in need of more work.

Step 6: Helping students extend their learning to action. This became possible through asking the students to use what they had learned in speaking about different issues, lecturing about various topics, taking part in debates and discussions in English and if possible use what they had learned in the social media to find international friends, watch films, and solve the daily life issues and enjoy living through the English language world. A summary of the ENGAGE Model used in the present study is given in Table 1 below. 
ENGAGE Model as an Innovation in Teaching Speaking: A Case of

Cognitively More and Less Active EFL Learners

Table 1: A Summary of the ENGAGE Model in the EFL Classroom

\begin{tabular}{|c|c|c|c|c|}
\hline Step & $\begin{array}{c}\text { Learning } \\
\text { Process }\end{array}$ & Activity Types & Examples & Homework \\
\hline 1 & $\begin{array}{l}\text { Energizing } \\
\text { Learners }\end{array}$ & $\begin{array}{l}\text { Warm ups, ice-breaking } \\
\text { discussions, talking } \\
\text { about daily life issues, } \\
\text { and motivating students } \\
\text { through using gestures } \\
\text { and postures }\end{array}$ & $\begin{array}{l}\text {-Think about what it has taken } \\
\text { for you to give up work, family, } \\
\text { or private time to learn } \\
\text { something new. } \\
\text { - What do you remember about } \\
\text { a particular class you attended } \\
\text { that motivated you to feel } \\
\text { excited before you even got } \\
\text { there? }\end{array}$ & $\begin{array}{l}\text {-Do a quick Internet search on } \\
\text { your subject (making friends). } \\
\text {-Interview two people before } \\
\text { your class. } \\
\text {-Develop interview questions and } \\
\text { bring them to the class. }\end{array}$ \\
\hline 2 & $\begin{array}{l}\text { Navigating } \\
\text { Content }\end{array}$ & $\begin{array}{l}\text { Asking the students to } \\
\text { navigate what they have } \\
\text { gained in the energizing } \\
\text { session and develop the } \\
\text { new content. }\end{array}$ & $\begin{array}{l}\text { - Teachers and learners } \\
\text { negotiate on decisions to be } \\
\text { made about assignments, } \\
\text { activities }\end{array}$ & $\begin{array}{l}\text {-Use stories that embed the } \\
\text { learning. } \\
\text {-Think/pair/share-think about } \\
\text { something, then pair up with } \\
\text { someone and share it with them. } \\
\text {-Practice a skill and then describe } \\
\text { to a partner what they are actually } \\
\text { doing as they are doing the skill }\end{array}$ \\
\hline 3 & $\begin{array}{l}\text { Generating } \\
\text { Meaning }\end{array}$ & $\begin{array}{l}\text { Asking the students to } \\
\text { present oral reports to } \\
\text { the classroom about the } \\
\text { current events, their life } \\
\text { and their feelings about } \\
\text { recent events in the } \\
\text { immediate social context } \\
\text { and the like. }\end{array}$ & $\begin{array}{l}\text { - Which objective is most } \\
\text { important to you? Creating } \\
\text { dynamic meetings or Creating a } \\
\text { one-day workshop. } \\
\text { - Now think about why this is } \\
\text { important for you. } \\
\text { - How will your knowledge of } \\
\text { the importance of generating } \\
\text { meaning impact } \\
\text { your future learning endeavors? }\end{array}$ & $\begin{array}{l}\text { Discuss the following topics for } \\
\text { the next session. } \\
\text { - When was the last time you } \\
\text { remember someone helping you } \\
\text { to generate meaning regarding } \\
\text { your learning? } \\
\text { - What did the facilitation do to } \\
\text { help you discover the value of the } \\
\text { new concepts in your life? }\end{array}$ \\
\hline 4 & $\begin{array}{l}\text { Applying to } \\
\text { Real World }\end{array}$ & $\begin{array}{l}\text { Asking the students } \\
\text { study about the topic } \\
\text { selected in the } \\
\text { classroom. }\end{array}$ & $\begin{array}{l}\text { - Use the internet, get involved } \\
\text { in the social media, collect } \\
\text { information about a specific } \\
\text { issue, and then present your } \\
\text { own perspectives in the } \\
\text { classroom. } \\
\text { - Students will cover an article } \\
\text { about giving advice. } \\
\text { Should the students be } \\
\text { interested in this issue, the } \\
\text { researcher may decide to use it } \\
\text { for an interview or conversation } \\
\text { topic. }\end{array}$ & $\begin{array}{l}\text { - Talk about the effect of making } \\
\text { new friends and having a network } \\
\text { of people around. }\end{array}$ \\
\hline 5 & $\begin{array}{l}\text { Gauging and } \\
\text { Celebrating }\end{array}$ & $\begin{array}{l}\text { Employing self- } \\
\text { assessment (SA) in the } \\
\text { classroom context. } \\
\text { Teaching SA principles } \\
\text { and how to develop self- } \\
\text { assessment speaking } \\
\text { checklists. } \\
\text { Practicing self- } \\
\text { assessment on the } \\
\text { speaking activities and } \\
\text { tasks. Scoring self- } \\
\text { performance based on } \\
\text { the checklist. }\end{array}$ & $\begin{array}{l}\text { Students are asked to assess } \\
\text { themselves at the end of each } \\
\text { session of the classroom and see } \\
\text { how well they learn what is } \\
\text { taught. } \\
\text { Students receive relative } \\
\text { feedback by the teacher, } \\
\text { something which is decreased } \\
\text { as the learners increase in the } \\
\text { quality of their self-assessment. } \\
\text { Various quizzes and classroom } \\
\text { discussions will be presented in } \\
\text { the intervention sessions. }\end{array}$ & $\begin{array}{l}\text { - Record a talk and send it to your } \\
\text { friends and receive responses. } \\
\text { - Use the sentences of from } \\
\text { different sources and the internet } \\
\text { to make questions and asks each } \\
\text { other to complete the exam papers } \\
\text { they have developed. } \\
\text { - Evaluate yourself as being } \\
\text { excellent, good, bad, or in need of } \\
\text { more work. }\end{array}$ \\
\hline
\end{tabular}


Esfandiari, Mahmoudi, Davaribina

\begin{tabular}{|c|c|c|c|c|}
\hline Step & $\begin{array}{c}\text { Learning } \\
\text { Process }\end{array}$ & Activity Types & Examples & Homework \\
\hline 6 & $\begin{array}{l}\text { Extending } \\
\text { Learning to } \\
\text { Action }\end{array}$ & $\begin{array}{l}\text { Asking the students to } \\
\text { use what they have } \\
\text { learned in speaking } \\
\text { about different issues. }\end{array}$ & $\begin{array}{l}\text { Lecture about various topics, } \\
\text { take part in debates and } \\
\text { discussions in English and if } \\
\text { possible use what you have } \\
\text { learned in the social media to } \\
\text { find international friends, watch } \\
\text { films, and solve the daily life } \\
\text { issues and enjoy living through } \\
\text { the English language world. }\end{array}$ & $\begin{array}{l}\text { - How will you extend your } \\
\text { learning so you have a greater } \\
\text { transfer from learning to } \\
\text { achieving business results through } \\
\text { application of new skills? } \\
\text { - What other great ideas keep } \\
\text { learning alive for you? }\end{array}$ \\
\hline
\end{tabular}

In the control group (the TBLT Group), the teacher, who was one of the researchers, focused on TBLT, an extension of the principles of Communicative Language Teaching (CLT). Task-based language teaching, which can be seen as the strong version of CLT, recommends language use as the main aim of language learning (Ellis 2009). Ellis (2003) states that "in TBLT the syllabus specifications are based on communicative tasks and not on notions and functions or grammatical structure" (123). Nunan (2006) has defined communicative pedagogical tasks as those pieces of classroom activities involving learners in comprehension, manipulation, production or interaction in the target language with their attention primarily concentrated on the meaning instead of the form (24). A good number of studies have already proved the significant impact of TBLT on the L2 speaking development in both ESL and EFL contexts (Buriro and Hayat 2010; Ellis 2009; Hismanoglu and Hismanoglu 2011; Prabhu 1987; Rohani 2011; Yamada and Knight 2001; Zheng and Borg 2014). Moreover, it is possible to support the students to express meanings and assist them in the development of linguistic forms with the application of recasts and prompts (Guchte et al. 2015).

More specifically, the researchers employed the procedure and tasks presented by Prabhu (1987), Willis (2019), Ellis (2003), and Nunan (2006) in the TBLT group. In the present study, the researchers relied on task-supported language teaching which represented a weak version of TBLT (Ellis 2003) that uses tasks to make language teaching more communicative. Considering task-supported language teaching, Ellis (2003) states that "tasks are seen not as a means by which learners acquire new knowledge or restructure their inter-languages but simply as a means by which learners can activate their existing knowledge of the L2 by developing fluency" (30). Also, pedagogical tasks were used in this group as they were more controlled than the real-life tasks and could be used more effectively in the classroom with regard to the current status of the participants' knowledge of L2 speaking.

The type of feedback this group mostly relied on was peer feedback and the students employed explicit corrective feedback, which was in line with the suggestions of Ellis (2009) in terms of the peer Corrective Feedback (CF), especially in terms of grammar and vocabulary, though CF on content was also encouraged among them. It is worth mentioning that the final performance of the students were checked by the teacher (one of the researchers) for more clarification and to help the learners improve their L2 speaking abilities. The teacher used Oral Corrective Feedback (OCF) to draw the learners' attention toward their mistakes and likely errors. However, the teacher did not interrupt them while they were speaking. Nor did he fine-tune their production. This resulted in a less stressful situation for the 
ENGAGE Model as an Innovation in Teaching Speaking: A Case of

Cognitively More and Less Active EFL Learners

learners. Meanwhile, the feedback was given to the learners for their speaking at the end of their speaking period. After the intervention, the participants in the experimental and control groups received the speaking post-test.

\section{Results}

The first research question of the study aimed at finding if the ENGAGE Model had any statistically significant effect on the speaking development of cognitively less active EFL learners. One of the descriptive statistics tests that was necessary to be used was the normality test, to make sure that using parametric tests for inferential analyses was permitted. All main sets of scores used in the data analysis section were subjected to this test the results of which revealed that other than the pre-test speaking result, all of the other score sets have had normal distributions. Therefore, the researchers used the nonparametric alternative of the Paired-samples T-test, that is Wilcoxon Signed-Rank test. The Wilcoxon Signed-Rank test shows that the answer to this question is YES and the null hypothesis should be rejected. Table 2 is the Hypothesis Test Summary along with the decision that should be taken into consideration.

Table 2: Hypothesis Test Summary.

\begin{tabular}{lllll}
\hline & Null Hypothesis & Test & Sig. & Decision \\
\hline Group = ENGAGE, & The median of differences & Related examples: & .000 & Reject the Null \\
Cognitive Level = & between Pre speaking and post & Wilcoxon Signified & & Hypothesis \\
Less Active & speaking equals 0 & Rank Test & & \\
\hline
\end{tabular}

*Note. Asymptomatic differences are displayed. The significance level is.05.

The Related Samples Test View and the Continuous Field Information represented below also refer to this finding with $t=463, \mathrm{p}=.000<.05$. The value of " $t$ " is equal to the difference between the pretest and posttest's mean ranks divided by the standard error of mean. The size of " $t$ " and the significance value indicate that the improvement has been substantial. The Continuous Field Information graph presents that except for one participant all ranked participants in the group have made significant gains

from the pre-test to the post-test. The effect size value for this test was calculated using the $\mathrm{r}=\frac{z}{\sqrt{w}}$ equation and the result was very high. The effect size value for this test was calculated to be, $r=.86$. 


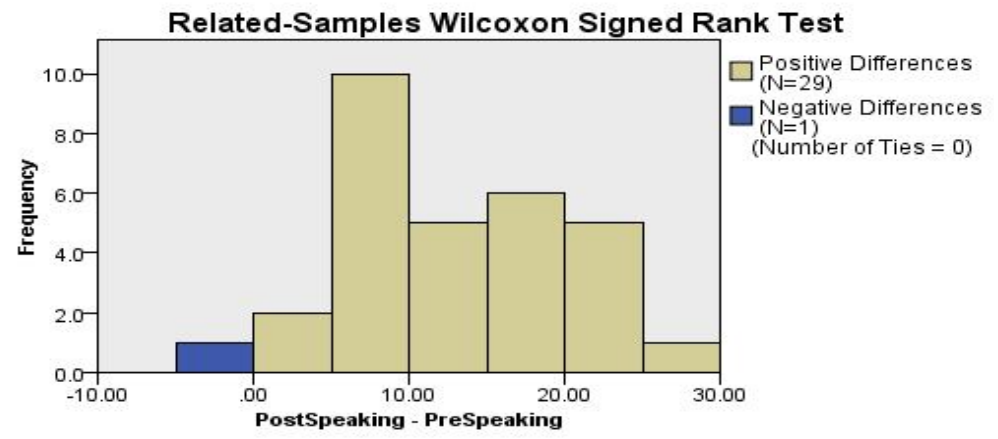

\begin{tabular}{|lr|}
\hline Total N & 30 \\
\hline Test Statistic & 463.000 \\
\hline Standard Error & 48.593 \\
\hline Standardized Test Statistic & 4.744 \\
\hline Asymptotic Sig. (2-sided test) & .000 \\
\hline
\end{tabular}

Figure 1: Speaking Pretest-Posttest Continuous Field Information of Cognitively Less Active Learners.

The second research question of this study aimed at finding if the ENGAGE Model had any statistically significant effect on the speaking development of cognitively more active EFL learners. The Wilcoxon Signed-Rank test revealed that we should give a positive answer to this question and reject the null hypothesis. Table 3 is the Hypothesis Test Summary along with the decision that should be made.

Table 3: Hypothesis Test Summary.

\begin{tabular}{lllll}
\hline & Null Hypothesis & Test & Sig. & Decision \\
\hline Group $=$ & The median of differences & Related examples: & .000 & Reject the Null \\
$\begin{array}{l}\text { ENGAGE, } \\
\text { Cognitive Level }= \\
\text { More Active }\end{array}$ & between Pre speaking and post & Wilcoxon Signified & & Hypothesis \\
& speaking equals 0 & Rank Test & & \\
\hline Note. Asymptomatic differences are displayed. The significance level is.05. &
\end{tabular}

*Note. Asymptomatic differences are displayed. The significance level is.05.

The Related Samples Test View and the Continuous Field Information visuals below point to this finding with $t=433, \mathrm{p}=.000<.05$. The size of " $t$ " and the significance value indicate that this finding is very significant. The Continuous Field Information graph too revealed that all ranked participants in the group have made gains from the pre-test to the post-test. The effect size value for this test was calculated and the result was very high $(r=.86)$. 
ENGAGE Model as an Innovation in Teaching Speaking: A Case of

Cognitively More and Less Active EFL Learners

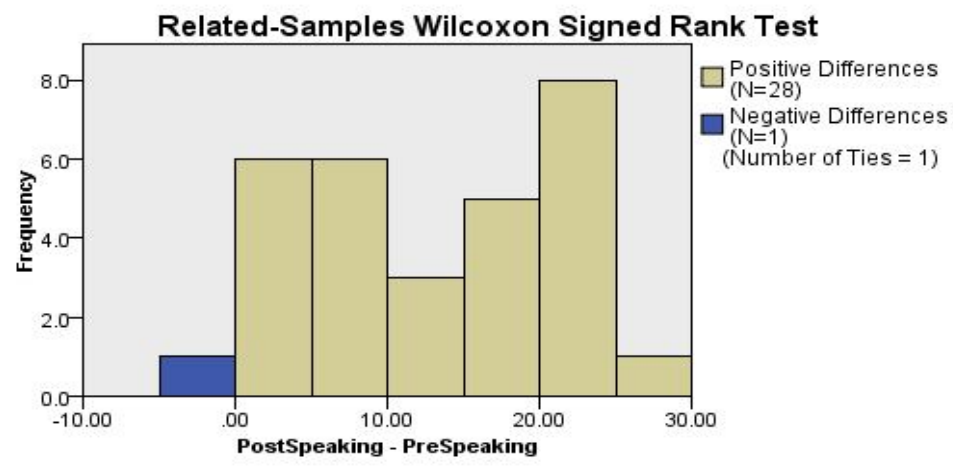

\begin{tabular}{|lr|}
\hline Total N & 30 \\
\hline Test Statistic & 433.500 \\
\hline Standard Error & 46.222 \\
\hline Standardized Test Statistic & 4.673 \\
\hline Asymptotic Sig. (2-sided test) & .000 \\
\hline
\end{tabular}

Figure 2: Speaking Pretest-Posttest Continuous Field Information of Cognitively More Active Learners.

The third research question of the study was an attempt to see whether cognitively more and less active EFL learners differ significantly in their speaking performance in response to being taught with the TBLT or the ENGAGE Model. The first ANCOVA test results run on the post-test speaking ability scores controlling for difference in the pre-test speaking ability as the covariate are given in tables 4 to 9 .

Table 4: Between-Subjects Factors; Speaking Post-test.

\begin{tabular}{llll}
\hline & & Value Label & $\mathbf{N}$ \\
\hline Group & 1 & ENGAGE & 30 \\
& 2 & TBLT & 30 \\
\hline Cognitive Level & 1 & Less & 30 \\
& 2 & More & 30 \\
\hline
\end{tabular}

Table 5: Descriptive Statistics; Speaking Post-test as the Dependent Variable.

\begin{tabular}{lcccc}
\hline Group & Cognitive Level & Mean & Std. Deviation & N \\
\hline ENGAGE & Less & 44.67 & 4.433 & 18 \\
& More & 44.92 & 5.230 & 12 \\
& Total & 44.77 & 4.681 & 30 \\
\hline TBLT & Less & 29.92 & 3.423 & 12 \\
& More & 30.67 & 4.982 & 18 \\
& Total & 30.37 & 4.375 & 30 \\
\hline Total & Less & 38.77 & 8.365 & 30 \\
& More & 36.37 & 8.680 & 30 \\
& Total & 37.57 & 8.538 & 60 \\
\hline
\end{tabular}


Table 6: Levene's Test of Equality of Error Variances ${ }^{\mathrm{a}}$; Speaking Post-test.

\begin{tabular}{llll}
\hline F & df1 & df2 & Sig. \\
\hline .853 & 3 & 56 & .471 \\
\hline
\end{tabular}

Note. The Levene's test shows that the error variance of the dependent variable is equal across groups. a. Design: Intercept + Speaking Pretest + Group + Cognitive Level + Group

* Cognitive Level

Table 7: Tests of Between-Subjects Effects; Speaking Post-test as the Dependent Variable

\begin{tabular}{lcccccc}
\hline Source & Type III Sum of Squares & df & Mean Square & F & Sig. & $\begin{array}{c}\text { Partial Eta } \\
\text { Squared }\end{array}$ \\
\hline Corrected Model & $3198.657^{\mathrm{a}}$ & 4 & 799.664 & 39.908 & .000 & .744 \\
Intercept & 1217.901 & 1 & 1217.901 & 60.780 & .000 & .525 \\
Pretest Speaking & 83.757 & 1 & 83.757 & 4.180 & .046 & .071 \\
Group & 2416.921 & 1 & 2416.921 & 120.618 & .000 & .687 \\
Cognitive Level & 20.278 & 1 & 20.278 & 1.012 & .319 & .018 \\
Group & 1.781 & 1 & 1.781 & .089 & .767 & .002 \\
*Cognitive Level & 1102.076 & 55 & 20.038 & & & \\
Error & 60 & & & & \\
Total & & 59 & & & & \\
Corrected Total & & & & & & \\
\hline
\end{tabular}

a. R Squared =.744 (Adjusted R Squared $=.725$ )

Table 8: Covariates of Speaking Post-test by Groups.

\begin{tabular}{lllll}
\hline \multirow{2}{*}{ Group } & Mean & Std. Error & \multicolumn{2}{l}{$\mathbf{9 5 \%}$ Confidence Interval } \\
\cline { 4 - 5 } & & Lower Bound & Upper Bound \\
\hline ENGAGE & $44.444^{\mathrm{a}}$ & .851 & 42.738 & 46.150 \\
TBLT & $30.762^{\mathrm{a}}$ & .865 & 29.028 & 32.496 \\
\hline
\end{tabular}

a. Covariates appearing in the model are evaluated at the following values: Speaking Pretest $=25.23$.

Table 9: Covariates of Speaking Post-test by Cognitive Level

\begin{tabular}{lllll}
\hline \multirow{2}{*}{ Cognitive Level } & \multirow{2}{*}{ Mean } & Std. Error & \multicolumn{2}{c}{ 95\% Confidence Interval } \\
\cline { 4 - 5 } & & & Lower Bound & Upper Bound \\
\hline Moss & $36.982^{\mathrm{a}}$ & .848 & 35.283 & 38.681 \\
\hline
\end{tabular}

a. Covariates appearing in the model are evaluated at the following values: Speaking Pretest = 25.23 .

The most important table in this series of tables is the Tests of Between-Subjects Effects. What this table tells us is that after controlling for the effect of differences in the pre-test, it is only group membership that has brought about a significant difference $(F=120.6, d f=1, p=.0001<001, r=.678)$. The effect size, as can be seen, is large. To understand the direction of differences, we have to look at the means in the group membership and cognitive profile levels (the last two tables). For group membership, i.e., the ENGAGE Model and TBLT, we have 44.44 and 30.76 as the students' post-test speaking means respectively hugely in favor of the ENGAGE Model group. For cognitive profile, i.e., cognitively less and more active groups, we have the means of 36.98 and 38.22 as the students' post-test speaking results respectively which are not too much different from each other even though the cognitively more active students fare better. The conclusion that can be reached is that, the students in the ENGAGE Model group outperformed students in the TBLT group in terms of their speaking ability, regardless of whether they 
ENGAGE Model as an Innovation in Teaching Speaking: A Case of

Cognitively More and Less Active EFL Learners

belonged to the cognitively less or more active groups. Thus, the aforementioned null hypothesis as "cognitively more and less active EFL learners do not differ significantly in their speaking performance in response to being taught with the TBLT or the ENGAGE Model", was rejected.

\section{Discussion}

The results of the data analysis firstly revealed that the ENGAGE Model had a statistically significant effect on the speaking development of cognitively more and less active EFL learners alike. This finding is in line with the previous studies on the effect of the ENGAGE Model in the educational domain, for example, Hodge et al. (2009), who investigated the impact of engaged learning on enabling self-authorship and effective practice. In their study, the ENGAGE Model of learning helped the learners move toward more autonomous and active learning. The success of the ENGAGE Model in the L2 speaking is also in line with Kojuri, et al.'s (2015) study on the use of Q2 Engage model (EQ2) for educational scholarship in Shiraz University of Medical Sciences (SUMS). They found that this model was beneficial to the students as it involved them in the various aspects of a problem. The multidimensionality and dynamic nature of the ENGAGE Model (Halsey 2016) have given rise to the development of scholarship among the aforementioned students. This is what the first finding of the current study is also indicative of.

The present study can also take support from Halsey and Halsey's (2017) study on connecting Californians with the Chaparral wildlife project through the ENGAGE Model in which they designed an educational program mainly relying on environmental issues. Since both cognitively more and less active learners in the present study positively improved in their L2 speaking irrespective of their cognition level, it can be argued that the ENGAGE Model has been helpful in making individuals with different cognitive orientations active in an educational setting. This in itself can take support from cognitive learning assumption of modularity (Chomsky 1979; Fodor 1983). In fact, the assumed language module in which L2 speaking can be placed presumptuously works actively with less reliance on the broad concept of cognition. That is why individuals with different cognitive levels can develop their L1 effectively, if not perfectly in some specific cases (Coltheart 2001).

The present study findings also revealed that the ENGAGE Model group outperformed the students in the TBLT group in terms of their L2 speaking, regardless of whether they belonged to the cognitively less or more active groups. As this is supposedly the first time the ENGAGE Model has been used in the domain of L2 classroom, the implications of the ENGAGE Model for ESL classes can be discussed with more confidence and elaboration hereafter. Some important points are given a more detailed discussion below while taking elements of the ENGAGE Model into consideration.

The first point worth mentioning is that the superiority of ENGAGE-based L2 speaking model over TBLT, which has been one of the most successful methods in the ELT domain (Ellis, et al. 2019), is intriguing and attractive. This indicates that, irrespective of its novelty and lack of a solid theoretical linguistic background for teaching, it has been immensely successful. The reason might lie in the shortcomings of TBLT such as putting too much emphasis on tasks and communicating meaning which 
could have an impact on how to use the language with the correct form (Seedhouse 1999), relying too much on the performing tasks which could be boring and tiresome (Ellis 2018), not being executed so ideally as it has been proposed and intensifying the danger of affecting the growth and change of the language learners' interlanguage (Skehan 2003), increasing fossilization because of fine tuning the mistakes and errors (Richards and Rodgers 2001), and "its unproven hypotheses and claims asserting that linguistic regularities are acquired through 'noticing' during communicative activity" (Swan 2005, 376).

Having been inspired by Halsey's ENGAGE Model, Kilbourne (2011) developed his own model for improving safety training which relied on the three notions of connect, inspire, and ENGAGE. As he believed, trainers require spending more time to think about the ways through which they want to teach instead of the material or content which is going to be taught. In fact, implicitly he refers to the significance of metacognitive strategies (Novak 1990; Oxford 1989). In this regard, the present study findings could find support in the learning psychology operationalized in the preplanning of activities before training the learners. Trainers usually spend $70 \%$ of their time concentrating on the content they are supposed to teach and just $30 \%$ of the time is spent on the ways through which teaching is going to take place. However, Halsey (2011) mentions that it should be the opposite.

Halsey et al. (2018) highlight the educational aspects of the ENGAGE Model asserting that the six steps of the model can pave the way for the success of learners. They indicate that the ENGAGE Model which has been designed based on discoveries in neuroscience can stimulate active learning and increase retention (Kilbourne 2011). Given the interconnections of neuroscience and cognition as well as cognitive neuroscience, since the scientific field concentrates on the study of biological processes and dimensions which are fundamental to cognition and is mostly concerned with the neural connections in the brain involved in mental processing, it seems logical to conclude that learning in the ENGAGE Model benefits from a cognitive orientation. Therefore, it can be assumed that L2 speaking development of the participants has been affected by their cognition and metacognitive strategies operationalized in the ENGAGE Model.

In terms of educational significance of the ENGAGE Model, Rundel (2018) mentioned that the ENGAGE Model can be used in different educational settings. It is likely that EFL learners not only improve their L2 abilities through paying attention to such concepts as the environment and social life, but also they learn how to connect what they read and learn to the immediate social or environmental context.

The success of the ENGAGE Model in the present study is also supported by Kim et al.'s (2017) study on the impact of using the ENGAGE Model in the domain of nursing practices which found benefits of a regional Evidence-Based Practice (EBP) fellowship program. In this regard, they found "improvement in EBP beliefs had direct impacts on developments in job satisfaction of the participants" (90). It is assumed that the L2 learners taking part in the present study also benefited from navigating content and connecting their learning to real life situations.

Likewise, the ENGAGE Model has inspired the development of a model for teaching clinical skills in the helping professions namely, Learn, Expand, and Engage (LEE) (Glance et al. 2018). LEE has been 
ENGAGE Model as an Innovation in Teaching Speaking: A Case of

Cognitively More and Less Active EFL Learners

drawn upon foundations in constructivist philosophies and learner-centered and flipped-classroom pedagogies. On the other hand this teaching model relies on Bloom's taxonomy and its highest processing levels. It can be argued that the principles presented in LEE, supported by the ENGAGE Model, might be found useful, should they be used in the EFL classroom.

It is crystal clear that L2 speaking is essential for communication between interlocutors. L2 development has also been notified as a life learning concept (Leki 2017). From this perspective the present findings are in line with another study conducted by Underwood et al. (2018) which has been inspired by the ENGAGE Model. They proposed that the ENGAGE Model can be used for curriculum development in educational settings aiming at paving the ground for heightened awareness toward the environment, wild life, global issues, and consequently more responsible learning and preparation for lifelong learning.

\section{Conclusion}

The results of the data analysis indicated that the participants in the experimental group had significant outperformance compared to the control group. Thus, it can be clearly concluded that the proposed treatment, which was the application of the ENGAGE Model, had been helpful for the participants in the experimental group to outperform the participants in the control group in which the teacher relied on TBLT techniques. This finding has been in line with some previous research from different perspectives (Glance et al. 2018; Housen and Simoens 2016; Kim et al. 2017; Nodine 2016; Waddington 2017). The results of the present study showed that experiencing the ENGAGE Model resulted in better speaking command in the learners compared to learners undergoing TBLT. It was revealed that this method can lead to higher strategic L2 speaking development in an EFL context. This implicates that ENGAGE-based teaching techniques might provide a better learning context for EFL learners' L2 speaking compared to those of the TBLT method, even though it still needs more studies to come up with a solid conclusion. Also, compared to the cognitively less active learners, cognitively more active EFL learners benefited more from the ENGAGE Model presented, though the model was novel to the ELT domain. To conclude, it seems that the ENGAGE Model deserves serious attention to be given to it by all concerned individuals to bring out the best of educational endeavors, especially investment of time and money by many EFL/ESL learners.

In the present study, the researchers were faced with some limitations. The participants were limited to the male individuals. Hence, the findings of the study should be generalized cautiously in terms of gender issues. Only 60 homogeneous participants could be selected to take part in the study as the number of the intermediate level students in the institute where the study was carried out did not exceed 80.The institute in which the research was conducted had set specific regulations and norms for the teachers, learners, and the researchers working with them to follow. Therefore, presenting the ENGAGE Model as a novel concept was hard as the aforementioned regulations were sometimes violated in the process of carrying out the study. Consequently, the institute posed challenges such as finishing the intended course 
book on time, moving within the framework of the institute, and preparing the students for the final exam, to the researchers. Therefore, further research is needed for more elaboration.

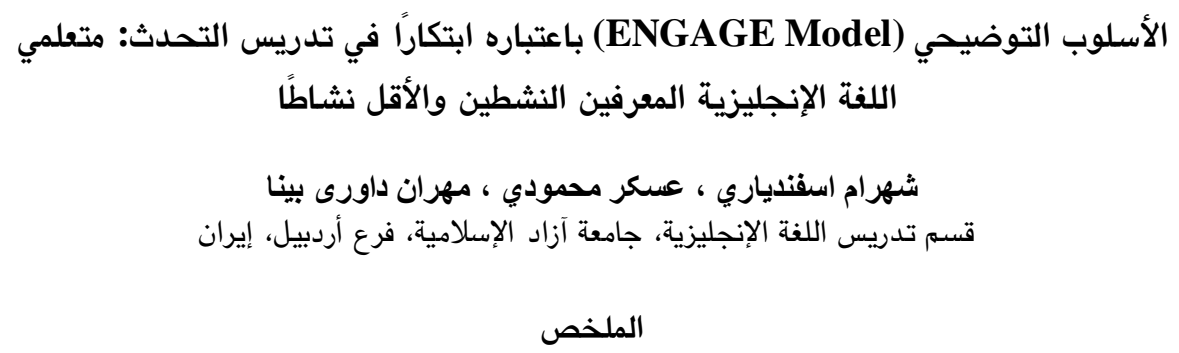


ENGAGE Model as an Innovation in Teaching Speaking: A Case of

Cognitively More and Less Active EFL Learners

\section{References}

Adams, Nancy E. 2015. Bloom's Taxonomy of Cognitive Learning Objectives. Journal of the Medical Library Association: JMLA 103 (3): 152.

Adams, Rebecca, and Jonathan Newton. 2009. TBLT in Asia: Constraints and Opportunities. Asian Journal of English Language Teaching19 (1):1-17.

Akbari, Zahra. 2015. Current Challenges in Teaching/Learning English for EFL Learners: The Case of Junior High School and High School. Procedia-Social and Behavioral Sciences 199: 394-401.

Albino, Gabriel. 2017. Improving Speaking Fluency in a Task-Based Language Teaching Approach: The Case of EFL Learners at PUNIV-Cazenga. Sage open 7 (2): 2158244017691077.

Aljumah, Fahad Hamad.2011. Developing Saudi EEF Students' Oral Skills: An Integrative Approach. English Language Teaching 4 (3): 84-89.

Anderson, Lorin W. and David R. Krathwohl. 2001. A Taxonomy for Learning, Teaching, And Assessing: A Revision of Bloom's Taxonomy of Educational Objectives, abridged edition." White Plains, NY: Longman 5 (1).

Asaoka, Chitose.2019. Early Professional Development in EFL Teaching. Multilingual Matters.

Borg, Simon, and Yousif Alshumaimeri. 2019. Language Learner Autonomy in a Tertiary Context: Teachers' Beliefs and Practices. Language Teaching Research 23 (1): 9-38.

Buriro, Ghulam Ali, and Tariq Hayat. 2010. Task-Based Learning: an in-Class ELT Experiment. Journal of Educational Research (1027-9776) 13 (2).

Cacioppo, John T., Gary G. Berntson, and Howard C. Nusbaum. 2008. Neuroimaging as a New Tool in The Toolbox of Psychological Science. Current Directions in Psychological Science 17 (2): 62-67.

Celce-Murcia, Marianne.2001. "Language teaching approaches: An overview." Teaching English as a second or foreign language 2 (1): 3-10.

Chomsky, Noam.1979. Language and Responsibility. New York: Pantheon.

Csikszentmihalyi, Mihaly.1996. Flow and the Psychology of Discovery and Invention. 56: 107.

Coltheart, Max. 2001. Assumptions and Methods in Cognitive Neuropsychology. The Handbook of Cognitive Neuropsychology: What Deficits Reveal about the Human Mind.3-21.

Ellis, Rod. 2003. Task-based Language Learning and Teaching. Oxford university press.

Ellis, Rod, and Rod R. Ellis. 2008. The study of Second Language Acquisition”. Oxford University.

Ellis, Rod. 2009. Task-Based Language Teaching: Sorting out the Misunderstandings. International Journal of Applied Linguistics 19 (3): 221-246.

Ellis, Rod. 2018. Reflections on Task-Based Language Teaching”. Multilingual Matters.

Ellis, Rod. W., Peter Skehan, Shaofeng Li., Natsuko Shintani and Craig Lambert. 2019. Task-Based Language Teaching: Theory and Practice. Cambridge: Cambridge University Press.

Eysenck, Michael W., and Mark T. Keane. 2013. Cognitive Psychology: A Student's Handbook. Psychology press.

Field, Andy. 2013. Discovering Statistics Using IBM SPSS statistics. Sage.

Fodor, Jerry A. 1983.The Modularity of Mind. MIT press. 
Esfandiari, Mahmoudi, Davaribina

Glance, Dorea, Alessandra Rhinehart, and Amanda Brown. 2018. Learn, Expand, Engage: Amodel for Teaching Clinical Skills in the Helping Professions. Adult Learning 29 (3):104-114.

Ghaemi, Farid, and Esmaeil Hassannejad. 2015. Developing EFL Students' Speaking: Brainstorming vs.

Role-Play. International Journal of Language Learning and Applied Linguistics World (IJLLALW) 8(4): 211-221.

Ghanizadeh, Afsaneh, Azam Razavi, and Akram Hosseini. 2018. TELL (Technology-Enhanced Language Learning) in Iranian High Schools: A Panacea for Emotional and Motivational

Detriments. International Journal of Applied Linguistics and English Literature 7 (4): 92-100.

Halsey, Richard. W. 2016. The first ten things I learned in the wilderness. Stop talking at me. Retrieved from www.californiachaparral.org/naturecenters.html.

Halsey, Richard W., Victoria W. Halsey, and Rochelle Gaudette. 2018. Connecting Californians with the Chaparral. Valuing Chaparral: 95-322. Springer, Cham.

Halsey, Victoria .W. 2011. Brilliance by design. San Francisco: Berrett-Koehler Publishers, Inc.

Halsey, Victoria. W. and Richard Halsey. W. 2017. Connecting Californians with the Chaparral through the ENGAGE Model.

Harley, Trevor A. 2004.Does Cognitive Neuropsychology Have a Future?Cognitive Neuropsychology 21 (1):3-16.

Hedge, Tricia.1993. Key Concepts In ELT. ELT journal 47 (3): 275-275.

Hismanoglu, Murat, and Sibel Hismanoglu.2011. Task-Based Language Teaching: What Every EFL Teacher Should Do. Procedia-Social and Behavioural Sciences 15: 46-52.

Hodge, David C., Marcia B. Baxter Magolda, and Carolyn A. Haynes.2009. Engaged Learning: Enabling Self-Authorship and Effective Practice. Liberal Education 95 (4): 16-23.

Housen, Alex, and Folkert Kuiken. 2009. Complexity, Accuracy, and Fluency in Second Language Acquisition. Applied linguistics 30 (4): 461-473.

Hughes, Rebecca, and Beatrice Szczepek Reed. 2016. Teaching and Researching Speaking. Routledge.

Jassem, Zaidan Ali, and Jassem Ali Jassem. 1997. Towards Better Speaking in English Major Classes: A Sociolinguistic Approach. The English Teacher 16: 1-10.

Kalyuga, Slava, and Anne-Marie Singh.2016. Rethinking the Boundaries of Cognitive Load Theory in Complex Learning." Educational Psychology Review 28 (4): 831-852.

Kang, Su-Ja. 2005. Dynamic Emergence of Situational Willingness to Communicate in a Second Language. System 33 (2): 277-292.

Kilbourne, Chris. 2011. Connect, inspire, and ENGAGE: A model for improving safety training. Retrieved September, 2, 2019, from https://ehsdailyadvisor.blr.com

Kim, Jungtae, and Daniel A. Craig. 2012. Validation of a Video Conferenced Speaking Test. Computer Assisted Language Learning 25 (3): 257-275.

Kim, Son Chae, Laurie Ecoff, Caroline E. Brown, Ana-Maria Gallo, Jaynelle F. Stichler, and Judy E. Davidson. 2017. Benefits of a Regional Evidence-Based Practice Fellowship Program: A Test of The ARCC Model." Worldviews on Evidence-Based Nursing 14 (2): 90-98. 
ENGAGE Model as an Innovation in Teaching Speaking: A Case of

Cognitively More and Less Active EFL Learners

Kojuri, Javad, Farnaz Takmil, Mitra Amini, and Parissa Nabeiei.2015. The use of Q2 Engage Model (EQ2) for Educational Scholarship in Shiraz University of Medical Sciences (SUMS)." Medical Teacher 37 (9): 885-886.

Kunnu, Wichuda, and Aungkana Sukwises. 2014. Teaching Speaking Skills to Adult English Language Learners through ALM. International Journal of Social, Education, Economics and Management Engineering 8 (8): 2702-5.

Leahy, Wayne, and John Sweller. 2016. Cognitive Load Theory and the Effects of Transient Information on the Modality Effect. Instructional Science 44 (1): 107-123.

Leki, Ilona.2017. Undergraduates in a Second Language: Challenges and Complexities of Academic Literacy Development. Routledge.

Long, Michael H., and Graham Crookes. 1992. Three Approaches to Task-Based Syllabus Design. TESOL quarterly 26 (1): 27-56.

Miyake, Akira, Naomi P. Friedman, Michael J. Emerson, Alexander H. Witzki, Amy Howerter, and Tor D. Wager. 2000. The Unity and Diversity of Executive Functions and Their Contributions to Complex "Frontal Lobe" Tasks: A Latent Variable Analysis. Cognitive psychology 41 (1): 49-100.

Murphy, R. S. 2019. EFL course book innovation: the dynamics of L2 maturity, student engagement, and cognitive development." PhD diss., University of Nottingham.

Nakatani, Yasuo. 2010. Identifying Strategies that Facilitate EFL Learners' Oral Communication: A Classroom Study Using Multiple Data Collection Procedures. The Modern Language Journal 94 (1): 116-136.

Nodine, Thad R. 2016. How Did We Get Here? A Brief History of Competency-Based Higher Education in the United States. The Journal of Competency-Based Education 1 (1): 5-11.

Novak, Joseph D. 1990. Concept Maps and Vee Diagrams: Two Metacognitive Tools to Facilitate Meaningful Learning. Instructional science 19 (1): 29-52.

Nunan, David. 2003."The impact of English as a global language on educational policies and practices in the Asia-Pacific Region." TESOL quarterly 37 (4): 589-613.

Nunan, David. 2006.Task-based language teaching. Cambridge: Ernst KlettSprachen.

Oxford, Rebecca L. 1989."Use of language learning strategies: A synthesis of studies with implications for strategy training." System 17 (2): 235-247.

Ockey, Gary J., Dennis Koyama, Eric Setoguchi, and Angela Sun. 2015. The Extent to which TOEFL iBT Speaking Scores Are Associated With Performance on Oral Language Tasks and Oral Ability Components for Japanese University Students. Language Testing 32 (1):39-62.

Pica, Teresa.1985. Input and Interaction in the Communicative Language Classroom: A Comparison of Teacher-Fronted and Group Activities. In S. Gass, \&amp; C. Madden (Eds.). Input in second language acquisition. Rowley, MA: Newbury House.

Prabhu, Neiman Stern. 1987. Second language pedagogy. Vol. 20. Oxford: Oxford University Press.

Rabab' ah, Ghaleb, and Ronza Abu Rumman.2015. Hedging in Political Discourse: Evidence from the Speeches of King Abdullah II of Jordan. Prague Journal of English Studies 4 (1): 157-185. 
Esfandiari, Mahmoudi, Davaribina

Richards, Jack Croft. 2008. Teaching Listening and Speaking. Cambridge: Cambridge university press.

Richards, Jack Croft, Jack C. Richards, and Willy A. Renandya, eds. 2002. Methodology in Language Teaching: An Anthology of Current Practice. Cambridge university press.

Rohani, Siti. 2011. Impact of Task-based Learning on Indonesian Tertiary EFL Students' Employment of Oral Communication Strategies. International Journal of Interdisciplinary Social Sciences 5 (10).

Rosenberg, Milton. J. and Abelson,Robert P. 2017. Symbolic Psycho-Logic: A Model of Attitudinal cognition. In A. Pelinka(Ed.). Attitude change: 86-115. London: Routledge.

Rundel, Philip W. 2018. California chaparral and its global significance. Valuing Chaparral: 1-27. Springer, Cham.

Safari, Parvin, and N. Rashida.2015. Teacher Education beyond Transmission: Challenges and Opportunities for Iranian Teachers of English. Issues in Educational Research 25 (2):187-203.

Soboleva, Aleksandra V. 2019. A Cognitive Style-Inclusive Approach as a Means of Learner-Centered EFL Teaching Mode Implementation. Handbook of Research on Curriculum Reform Initiatives in English Education: 122-135. IGI Global.

Sternberg, RobertJ. and karin Sternberg. 2009. Cognitive Psychology (6th Ed.). Belmont, CA:Wadsworth, Cengage Learning.

Sun, Ron. 2007. The importance of cognitive architectures: An Analysis Based on CLARION. Journal of Experimental \& Theoretical Artificial Intelligence 19 (2):159-193.

Sundqvist, Pia, and Liss Kerstin Sylvén.2016. Opening the Window for L2 English Development. In Extramural English in Teaching and Learning: 179-213. Palgrave Macmillan, London.

Tani, Massimiliano. 2005. Quiet, but only in class: Reviewing the in-Class Participation of Asian Students. Higher Education Research and Development Society of Australia Conference, Sydney, New South Wales. Retrieved September 5: 2007.

Toro, Vanessa, Gina Camacho-Minuche, Eliana Pinza-Tapia, and Fabian Paredes. 2019. The Use of the Communicative Language Teaching Approach to Improve Students' Oral Skills. English Language Teaching 12 (1):110-118.

Underwood, Emma C., Janet Franklin, Nicole A. Molinari, and Hugh D. Safford. 2018. (Eds.). Valuing Chaparral. Berlin: Springer.

Van De Guchte, Marrit, Martine Braaksma, Gert Rijlaarsdam, and Peter Bimmel. 2018. Learning New Grammatical Structures in Task-Based Language Learning: The Effects of Recasts and Prompts. The Modern Language Journal 99 (2): 246-262.

Waddington, Julie.2017. Competency-based ELT: Learning to Learn through our Storytelling Circle. APAC ELT Journal (85): 16-26.

Watts, Patricia, and Amanda Huensch. 2012. Integrated Speaking, Listening and Pronunciation: Are Textbooks Leading the Way. Proceedings of the 4th pronunciation in second language learning and teaching conference: $265-278$.

Yamada, Kenji, and Kevin Knight.2001. A Syntax-Based Statistical Translation Model. Proceedings of the 39th Annual Meeting of the Association for Computational Linguistics: 523-530. 
ENGAGE Model as an Innovation in Teaching Speaking: A Case of

Cognitively More and Less Active EFL Learners

Yang, Ya-Ting Carolyn, Ya-Chin Chuang, Lung-Yu Li, and Shin-Shang Tseng.2013. A Blended Learning Environment for Individualized English Listening and Speaking Integrating Critical Thinking. Computers \& Education 63: 285-305.

Zhang, Xi, Yao Meng, Patricia Ordóñez de Pablos, and Yongqiang Sun. 2019. Learning Analytics in Collaborative Learning Supported by Slack: From the Perspective of Engagement. Computers in Human Behavior 92: 625-633.

Zheng, Xinmin, and Simon Borg. 2014. Task-Based Learning and Teaching in China: Secondary School Teachers' Beliefs and Practices. Language teaching research 18 (2): 205-221. 